\title{
Analisis Keterlibatan Mahasiswa Sekolah Tinggi Ilmu Islam dan Bahasa Arab (STIBA) Makassar pada Lembaga Kemahasiswaan dan Efektifitasnya dalam Dakwah
}

\author{
Syandri \\ SekolahTingi Ilmu Islam dan Bahasa Arab (STIBA) Makassar \\ Syandri@stiba.ac.id \\ Askar Fatahuddin \\ SekolahTingi Ilmu Islam dan Bahasa Arab (STIBA) Makassar \\ askarfatahuddin@,stiba.ac.id \\ Ahmad Syaripudin \\ SekolahTingi Ilmu Islam dan Bahasa Arab (STIBA) Makassar \\ ahmadsyaripudin@stiba.ac.id \\ Agus Miranto \\ Sekolah'Tingi Ilmu Islam dan Bahasa Arab (STIBA) Makassar \\ agusmiranto579@gmail.com \\ Edwin Salnar Sose \\ SekolahTingi Ilmu Islam dan Bahasa Arab (STIBA) Makassar \\ edwinsalnar010@gmail.com
}

\begin{abstract}
This study aims to analyze the involvement of STIBA students in student organizations and their effectiveness in da'wah as a reference material for policy makers of the Makassar Islamic and Arabic Language College (STIBA) to establish better student regulations for the development of students and alumni of STIBA Makassar. The formulation of the first problem concerns the involvement of STIBA Makassar students in student institutions, the second is the effectiveness of da'wah for STIBA Makassar alumni at the Assignment location, and the third is an analysis of student involvement in $L K$ as well as resilience and creativity in da'wah. This research uses field research with qualitative analysis research methods, namely using in-depth data analysis in the form of numbers. The results of this study indicate that in general STIBA students during the study period have joined the Student Affairs Institute but the involvement tends to decrease from year to year. The effectiveness of the alumni's da'wah while at the job site is measured by militancy, resilience and creativity also needs intense guidance by the relevant sections within the scope of the STIB $A$ institution, while the correlation of student involvement in student institutions to the effectiveness of da'wah has proven to be quite positive even though most of it is only at the
\end{abstract}

Jurnal Dakwah dan Komunikasi

IAIN Curup-Bengkulu|E-ISSN: 2548-3366; P-ISSN: 2548-3293 
institutional level have not been able to do a lot of creative da'wab with other institutions externally.

Keywords: Analysis, Effectiveness of Da'wah, STIB A Alumni

\begin{abstract}
Abstrak
Penelitian ini bertujuan menganalisa keterlibatan mahasiswa STIBA dalam lembaga kemahasiswaan dan efektivitasnya dalam dakwah sebagai bahan acuan bagi pemangku kebijakan Sekolah Tinggi Ilmu Islam dan Bahasa Arab (STIBA) Makassar untuk menetapkan aturan-aturan kemahasiswaan yang lebih baik untuk pengembangan mahasiswa dan aumni STIBA Makassar. Rumusan masalah pertama mengenai keterlibatan mahasiswa STIBA Makassar dalam lembaga kemahasiswaan, kedua efektifitas dakwah alumni STIBA Makassar di lokasi Penugasan, dan ketiga adalah analisis keterlibatan mahasiswa dalam LK serta ketahanan dan kreatifitas dalam dakwah. Penelitian ini menggunakan adalah penelitian lapangan (Field Research) dengan metode penelitian analisis kualitatif yaitu menggunakan analisis data secara mendalam dalam bentuk angka. Hasil dari penelitian ini menunjukkan secara umum mahasiswa STIBA selama masa studi telah bergabung ke dalam Lembaga Kemahasiswaan akan tetapi keterlibatan tersebut cenderung menurun dari tahun ke tahun. Efektifitas dakwah alumni selama berada di lokasi tugas diukur dengan militansi, ketahanan dan kreatifitas juga perlu pembinaan yang intens oleh bagian terkait dalam lingkup institusi STIBA, adapun korelasi keterlibatan mahasiswa dalam lembaga kemahasiswan terhadap efektivitas dakwah terbukti cukup positif meskipun kebanyaannya hanya pada tataran internal lembaga saja dan belum mampu banyak melakukan kreatifitas dakwah dengan Lembaga lain secara eksternal.
\end{abstract}

Kata Kunci: Analisis, Efektivitas Dakwah, Alumni STIBA

\title{
Pendahuluan
}

Sekolah Tinggi Ilmu Islam dan Bahasa Arab (STIBA) Makassar adalah salah satu Institusi pendidikan keagaaman yang tidak hanya menitikberatkan programprogramnya pada kegiatan yang bersifat akademik di kelas saja. Intitusi dan mahasiswa juga membentuk Lembaga Kemahasiswaan sebagai salah satu hak mahasiswa untuk mengembangkan kemampuan intelektual, kemampuan sosial, dan religiusnya. ${ }^{1}$ Selain itu, LK di STIBA memiliki tujuan khusus yaitu sebagai wadah

${ }^{1}$ Faisal Hendra, "Peran Organisasi Mahasiswa Dalam Meningkatkan Mutu Pembelajaran Keterampilan Berbahasa Arab," Arabiyat: Jurnal Pendidikan Bahasa Arab Dan Kebahasaaraban 5, no. 1 (2018): 103-20, https://doi.org/10.15408/a.v5i1.7480. 
pembinaan menuju Visi dan Misi institusi secara khusus pembentukan mahasiswa yang memiliki berkarater Mukmin, Muslih, Mujahid, Mutaawin dan Mutqin (5M). ${ }^{2}$

Berhimpun ke dalam organisasi kemahasiswaan merupakan hak setiap mahasiswa. Seperti diatur dalam undang-undang Nomor 12 tahtun 2012 tentang Pendidikan Tinggi pasal 77 ayat 1 sampai 3 menyatakan bahwa: (1) Mahasiswa dapat membentuk organisasi kemahasiswaan, (2) Organisasi kemahasiswaan paling sedikit memeliki fungsi untuk: (a) Mewadahai kegiatan Mahasiswa dalam mengembangkan bakat, minat, dan potensi Mahasiswa; (b) Mengembangkan kreativitas, kepekaan, daya kritis, keberanian, dan kepemimpinan, serta rasa kebangsaan; (c) Memenuhi kepentingan dan kesejahteraan Mahasiswa; dan (d) Mengembangkan tanggung jawab sosial melalui kegiatan Pengabdian kepada Masyarakat (3) Organisasi kemahasiswaan sebagaimana dimaksud pada ayat (1) merupakan organisasi intra Perguruan Tinggi. 3

Lembaga kemahasiswaan adalah sebuah wadah pembelajaran mahasiswa untuk mengembangkan diri dalam berorganisasi, kepemimpinan, dan belajar menjalanankan kegiatan, dari mulai yang bersifat akademik maupun yang nonakademik. ${ }^{4}$ Tujuan dari lembaga mahasiswa didirikan yakni untuk membuat suatu lembaga pemerintahan internal kampus dengan tujuan membantu pencapaian visi suatu universitas. Tidak hanya itu, lembaga kemahasiswaan juga bertujuan untuk menanamkan budaya kritits dan kepekaan sosial kepada setiap mahasiswa terhadap internal universitas. ${ }^{5}$

Penjelasan diatas, pada dasarnya seluruh mahasiswa seyogyanya mengikuti salah satu unit dari Lembaga Kemahasiswaan di kampus masing-masing sebagai sebuah idealitas seorang mahasiswa untuk ikut serta dalam pembangunan dan mencerdaskan kehidupan bangsa. Sangat disayangkan kondisi prgamatis mahasiswa diberbagai kampus yang ada termaksud di STIBA sendiri, dari hasil pengamatan peneliti bahwa secara umum mahasiswa terbagi ke dalam beberapa klasifikasi, a) mahasiswa yang hanya fokus dengan studi, b) mahasiswa terlalu fokus pada organisasi, dan c) mahasiswayang mampu menggabungkan antara studi dan organisasi secara proporsional.

Data Report Tracer Study (Studi Penelusuran Alumni) STIBA Makassar menujukkan bahwa secara umum alumni telah mendapatkan tambahan keterampilan semasa studi di STIBA Makassar, meskipun dalam data tersebut belum dipaparkan secara detail persentase daya tahan alumni di wilayah tugas masing-masing dan

${ }^{2}$ Yayasan Pesantren Wahdah Islamiyah, "Statuta Sekolah Tinggi Ilmu Islam Dan Bahasa Arab (STIBA) Makassar,” Pub. L. No. Qr.24a/Ypwi/Ix/1440 (2019).

${ }^{3}$ Republik Indonesia, "UU No. 12 Nomor 2012," 2012.

${ }^{4}$ Menella Angelia Putri and Achmad Supriyanto, "Pembangunan Karakter Mahasiswa Melalui Keikutsertaan Dalam Organisasi Kemahasiswaan," in Seminar Nasional Arah Manajemen Sekolab Pada Masa Dan Pasca Pandemi Covid-19, 2020.

${ }^{5}$ Putri Bayina Rahma Nurdi, Syutri Laikuallo, and Alifia Meiliska, "Faktor-Faktor Yang Mempengaruhi Minat Mahasiswa Berorganisasi," Manor: Jurnal Manajemen Dan Organisasi Review 2, no. 2 (2020): 122-31. 
efektivitas tambahan keterampilan semasa studi dalam meningkatkan kreativitas dakwah. ${ }^{6}$ Demikian halnya pemetaan mahasiswa aktif di LK dan bisa bekerja serta aktif di lokasi dakwah belum dijelaskan secara baik. Bahkan secara lisan informasi dari stack holder ditemukan bahwa alumni STIBA menunjukkan partisipasi yang kurang di tempat dakwah bahkan cenderung stagnan dalam melaksanakan tugas di lokasi tugas.

Penelitian ini berfokus pada keterlibatan mahasiswa STIBA Makassar dalam Lembaga Kemahasiswaan dan efektivitasnya dalam dakwah dengan batasan objek penelitian hanya pada alumni tahun 20013-2018.

Berangkat dari latar belakang di atas, maka substansi masalah yang diangkat dalam penelitian berjudul "Analisis Keterlibatan Mahasiswa dalam LK dan Efektfitasnya dalam Dakwah" sebagai berikut:

1. Bagaimana keterlibatan mahasiswa STIBA Makassar dalam lembaga kemahasiswaan?

2. Bagaimana efektifitas dakwah alumni STIBA Makassar di lokasi Penugasan Dakwah?

3. Bagaimana analisis keterlibatan mahasiswa dalam LK serta ketahanan dan kreatifitas dalam dakwah?

Bagi sekolah-sekolah tinggi, institut, dan universitas di Indonesia, Lembaga Kemahasiswaan adalah suatu wadah yang mudah untuk ditemukan, justru akan menjadi sesuatu yang aneh jika suatu sekolah tinggi tidak mempunyai lembaga kemahasiswaan. Lembaga kemahasiswaan (intra kampus) di Indonesia sangat beragam, mulai dari Badan Eksekutif Mahasiswa (BEM) sebagai badan eksekutif dan Dewan Perwakilan Mahasiswa (DPM) sebagai badan legislatif di tingkat universitas maupun fakultas, dan Unit Kegiatan Mahasiswa (UKM) di tingkat universitas sebagai lembaga yang bergerak untuk mengembangkan bakat dan minat mahasiswa dalam bidang keagamaan, kesenian, olahraga, dan Himpunan Mahasiswa Jurusan (HMJ/HIMA) di setiap program studi atau tingkat jurusan. ${ }^{7}$

Tujuan didirikannya lembaga mahasiswa di setiap universitas, institut, maupun di sekolah-sekolah tinggi di seluruh Indonesia adalah untuk membantu para mahasiswa mengembangkan diri di bidang akademik maupun non-akademik ${ }^{8}$. Akan tetapi fenomena yang terjadi belakangan ini di kebanyakan kampus-kampus yang ada, lembaga mahasiswa justru keluar dari jalur atau visi kelembagaannya itu sendiri. Lembaga mahasiswa adalah suatu sarana terbaik untuk pembelajaran organisasi dan kepemimpinan di lingkungan internal kampus sekaligus untuk menciptakan rantai

'Pusat Penelitian et al., "Panduan Penelitian STIBA Sumber Dana PNBP Dan Mandiri," n.d.

${ }^{7}$ Kosasih Kosasih, "Peranan Organisasi Kemahasiswaan Dalam Pengembangan Civic Skills Mahasiswa," Jurnal Pendidikan Ilmu Sosial 25, no. 2 (2017): 188-98.

${ }^{8}$ Ahmad Almarogi, "Keterlibatan Senat Mahasiswa Universitas Dalam Tata Kelola Organisasi Intra Kampus: Studi Kasus Kampus Universitas Islam Negeri Sunan Gunung Djati Bandung" (UIN Sunan Gunung Djati Bandung, 2019). 
intelektual, budaya kritis terhadap segala sesuatu dan kepekaan sosial mahasiswa itu sendiri. ${ }^{9}$

Dakwah adalah merupakan tujuan akhir dari seluruh proses pembelajaran yang dilakukan oleh institusi STIBA Makassar mulai dari kegiatan formal di kelas ataupun kegiatan ekstrakulikuler. ${ }^{10}$ Akan tetapi realistas menunjukkan bahwa tidak sedikit dari alumni STIBA selama bertugas di tempat masing-masing belum mampu mengembangkan diri secara maksimal.

Penelitan berkaitan dengan efektivitas dan peran Lembaga Kemahasiswaan (LK) terhadap prestasi mahasiswa dalam luar kampus sudah cukup banyak dilakukan. Berikut peneliti sebutkan beberapa diantaranya:

1. Mustika Cahyani Pertiwi, dkk melakukan penelitian dengan tema Hubungan Organisasi dengan Mahasiswa dalam Menciptakan Leadership. Penelitian ini bertujuan untuk mengetahui peran UKM Ekspi terhadap minat berorganisasi Mahasiswa Pendidikan Guru sekolah Dasar UMS tahun 2014. Hasil penelitian ini menunjukkan bahwa sebanyak 60\% mahasiswa berminat mengikuti organisasi, yang tidak terlalu berminat dalam kegiatan ini sebanyak $20 \%$ dan yang tidak berminat mengikuti $20 \% .{ }^{11}$

2. Yunindra Widyatmoko, menuliskan sebuah skripsi dengan tema Pengaruh Keaktifan Mahasiswa Dalam Organisasi Dan Prestasi Belajar Terhadap Kesiapan Kerja Mahasiswa Jurusan Pendidikan Ekonomi Universitas Negeri Yogyakarta. Penelitian ini merupakan penelitian ex-post facto dengan pendekatan kuantitatif. Variabel dalam penelitian ini adalah keaktifan mahasiswa dalam organisasi, prestasi belajar, dan kesiapan kerja. Populasi dalam penelitian ini sebanyak 187 mahasiswa jurusan pendidikan ekonomi angkatan 2011 dan 2012. Teknik sampling yang digunakan pada penelitian ini adalah simple random sampling. Sampel penelitian berjumlah 87 mahasiswa dengan rincian 35 mahasiswa yang aktif dalam organisasi dan 52 mahasiswa yang tidak aktif dalam organisasi. Teknik pengumpulan data menggunakan angket dan dokumentasi. Teknik analisis data menggunakan regresi ganda. Hasil penelitian menunjukkan bahwa terdapat pengaruh signifikan keaktifan mahasiswa dalam organisasi dan prestasi belajar secara bersama-sama terhadap

9Sujarwo Sujarwo, "Peran Lembaga Kemahasiswaan Fakultas Dakwah Dan Komunikasi UINSU Dalam Menciptakan Keharmonisan Di Fakultas Dakwah Dan Komunikasi Universitas Islam Negeri Sumatera Utara" (Universitas islam Negeri Sumatera Utara, 2017).

${ }^{10}$ Samsuddin Samsuddin, Iskandar Iskandar, and Mariyanto Nurshamsul, "Pendidikan Kader Da'i Ormas Wahdah Islamiyah Melalui Halaqah Tarbiyah," Ta'dibuna: Jurnal Pendidikan Islam 9, no. 2 (2020): 283-300.

${ }^{11}$ Suwarno and Latifah Arifatul Farida, "Aktualisasi Bimbingan Dan Konseling Pada Pendidikan Dasar Menuju Peserta Didik Yang Berkarakter," Prosiding Seminar Nasional Dan Call For Papers ISBN: 978-, no. 2 (2015): 323-32. 
174 Jurnal Dakwah dan Komunikasi, Vol.6 No.2, 2021

kesiapan kerja mahasiswa jurusan pendidikan ekonomi dengan nilai Fhitung 14.451 dan signifikansi sebesar 0.000; terdapat pengaruh positif signifikan keaktifan mahasiswa dalam organisasi terhadap kesiapan kerja mahasiswa jurusan pendidikan ekonomi dengan nilai t hitung 4.282 dan signifikansi 0.000; terdapat pengaruh positif signifikan prestasi belajar terhadap kesiapan kerja mahasiswa jurusan pendidikan ekonomi dengan nilai t hitung 2.176 dan signifikansi $0.032 . .^{12}$

3. Kosasih menulis sebuah penelitian pada Jurnal Pendidikan Ilmu Sosial (JPIS) dengan tema Peranan Organisasi Kemahasiswaan Dalam Pengembangan Civic Skills Mahasiswa. Hasil dari penelitian ini menghasilkan temuan bahwa: motivasi mahasiswa terhadap ormawa mengalami penurunan karena lebih mengedepankan akademik dan dan dihadapkan tantangan gaya hidup yang mengarah pada hedonisme. Bentuk sosialisasi yang dilakukan organisasi kemahasiswaan dengan memanfaatkan berbagai media. Media yang efektif akan mempermudah dan menyebarluaskan informasi terkait kegiatan yang dilakukan oleh ormawa secara cepat dan akurat. Peranan ormawa terhadap pengembangan keterampilan kewarganegaraan mahasiswa yaitu sebagai wadah aspirasi mahasiswa dan memacu pola pikir mahasiswa agar berpikir secara kritis, bertanggungjawab, dan ilmiah. Kendala yang dihadapi ormawa selama pelaksanaan kegiatan terutama dalam pengembangan civic skills yaitu ada kendala secara internal dan eksternal. Misalnya, mengenai pendanaan, perizinan, gaya hidup, komunikasi dan koordinasi, kurangnya minat mahasiswa, latar belakang mahasiswa yang berbeda, fasilitas, dan mengenai secretariat. Upaya yang dilakukan ormawa yakni dengan melestarikan budaya, merancang program dan materi yang menarik, berperilaku disiplin, memahami manajemen konflik, mengadakan penilaian kinerja atau evaluasi, dan melaksanakan peran ormawa di universitas dengan sebaik mungkin ${ }^{13}$

4. Martina Kaisriani Rupa menulis sebuah penelitian skripsi dengan tema Alasanlasan Mahasiswa Tidak Ingin Terlibat dalam Organisasi Kemahasiswaan di Perguruan Tinggi. Dari analisisi penelitian ini menunjukkan bahwa mahasiswa Sanata Darma lebih suka terlibat di organisasi luar Kampus, lebih senang terlibat dalam kepanitian dan tidak ingin terikat dengan kontrak/waktu, merupakan alasan-alasan mahasiswa/i tidak ingin terlibat dalam organisasi kemahasiswaan. ${ }^{14}$

Secara umum penelitian ini bertujuan untuk mengetahui tentang peran Lembaga Kemahasiswaan (LK) dalam memberikan pengaruh terhadap pembangunan karakter dakwah mahasiswa, adapun secara khusus penelitian ini bertujuan untuk mengetahui dan mengidentifikasi: 1) bentuk-bentuk yang dilakukan

${ }^{12}$ Yunindra Widyatmoko, "Pengaruh Keaktifan Mahasiswa Dalam Organisasi Dan Prestasi Belajar Terhadap Kesiapan Kerja Mahasiswa Jurusan Pendidikan Ekonomi Universitas Negeri Yogyakarta" (Universitas Negeri Yogyakarta, 2014).

${ }^{13}$ Kosasih, "Peranan Organisasi Kemahasiswaan Dalam Pengembangan Civic Skills Mahasiswa."JurnalPendidikanIlmuSosial, (2017), 25.2: 188-198.

${ }^{14}$ Martina Kaisriani Rupa, "Alasan-Alasan Mahasiswa/I Tidak Ingin Terlibat Dalam Organisasi Kemahasiswaan Di Perguruan Tinggi," 2018, Yogyakarta. 
dalam Lembga Kemahasiswaan (LK) dalam meningkatkan kesadaran berorganisasi mahasiswa; 2) kekurangan dan kelebihan LK dalam mengingkatkan kesadaran beroragnisasi mahasiswa; 3) faktor-faktor yang menghambat mahasiswa dalam berpartisipasi dalam organisasi; 4) analisis manfaat keterlibatan mahasiswa dalam LK dan penerapannya dalam dakwah.

Penelitian ini juga bertujuan menjadi salah satu bahan evaluasi seluruh bagian yang berada dalam lingkup institusi untuk melakukan perubahan-perubahan kebijakan menuju STIBA yang lebih baik dan berkualitas melahirkan kader-kader dakwah yang memiliki kemampuan mengembangkan organisasi secara internal maupun eksternal.

Fokus pada penelitian ini adalah ada tiga komponen kemampuan alumni STIBA Makassar yaitu militansi, ketahanan, dan kreativitas. Militansi diukur dari ketahanan selama masa tugas $<2$ tahun mahasiswa yang mengikuti LK. Ketahanan yang diukur dengan kemampuan menyelesaikan problematika dakwah selama tugas. Indikator ketiga yaitu kreatifitas yang meliputi kemampuan menggunakan media dakwah, komunikasi tokoh masyarakat dan pemerintah.

Jenis penelitian ini adalah penelitian lapangan (field research) yakni pengamatan langsung terhadap obyek yang diteliti guna mendapatkan data yangrelevan. ${ }^{15}$ Metode yang akan digunakan dalam penelitian ini adalah dengan menggunakan metode penelitian analisis kuantitatif, yaitu menggunakan analisis data secara mendalam dalam bentuk angka dengan metode pengumpulan data berdasarkan Metode Angket (Kuesioner). ${ }^{16}$

Ada dua jenis data yang digunakan dalam penelitian ini, yaitu data primer dan data sekunder.Data primer adalah data yang didapatkan peneliti dari sumber pertama baik individu atau perseorangan seperti hasil wawancara atau pengisian kuesioner yang biasa dilakukan oleh peneliti. ${ }^{17}$ Sumber data primer dalam penelitian ini yaitu terfokus pada alumni STIBA Makassar pada rentang tahun 2013-2018. Meskipun setelah melihat kurangnya responden yang dap Pembatasan tahun dan jenis kelamin dilakukan untuk memudahkan pencarian sampel penelitian. Untuk mendapatkan data yang dibutuhkan, peneliti menyebarkan angket secara online.

Data sekunder merupakan data yang diperoleh atau dikumpulkan melalui buku-buku, brosur dan artikel yang di dapat dari website yang berkaitan dengan penelitian. ${ }^{18}$ Atau data yang berasal dari orang-orang kedua atau bukan data yang datang secara langsung, data ini mendukung pembahasan dan penelitian, untuk itu

${ }^{15}$ Azizah Indriyani, "Manajemen Sdm Dalam Upaya Meningkatkan Mutu Dan Kualitas Pelayanan Di Ridwan Institute Cirebon,” Syntax 2, No. 8 (2020).

${ }^{16}$ Ayu Permata, Nova Yulita, and Sellia Juwita, "Pengaruh Pemahaman Ibu Tentang Perkembangan Motorik Anak Terhadap Perkembangan Motorik Anak," Jurnal Ilmiah Fisioterapi 2, no. 2 (2019): 44-49.

${ }^{17}$ Muhamad, Metode Penelitian Ekonomi Islam Pendekatan Kuantitatif (Jakarta: PT.Raja Grafindo Persada, 2008), h. 103.

${ }^{18}$ Burhan Bungin, Metodologi Penelitian Kuantitatif Komunikasi, Ekonomi, Dan Kebijakan Publik Ilmu-Ilmu Sosial Lainya (Jakarta: Kencana, 2005), h. 122 
beberapa sumber buku atau data yang diperoleh akan membantu dan mengkaji secara kritis penelitian tersebut. ${ }^{19}$ Untuk memperoleh data tersebut peneliti mengambil beberapa buku, brosur, website, dan contoh penelitian sebelumnya yang berkaitan dengan penelitian ini.

Metode pengumpulan data merupakan salah satu aspek yang berperan dalam kelancaran dan keberhasilan dalam suatu penelitian. Dalam penelitian ini metode pengumpulan data yang digunakan adalah metode angket (kuesioner). ${ }^{20}$

Angket dan kuesioner adalah teknik pengumpulan data melalui formulirformulir yang berisi pertanyaan-pertanyaan yang diajukan secara tertulis pada seseorang atau sekumpulan orang untuk mendapatkan jawaban atau tanggapandan informasi yang diperlukan peneliti. ${ }^{21}$

Dalam penelitian ini, peneliti menggunakan metode Nonprobability Sampling yaitu Teknik pengambilan sampel yang tidak memberi peluang/kesempatan sama bagi setiap unsur atau anggota populasi untuk dipilih menjadi sampel. Secara khusus dengan mengggunakan sampling purposive yaitu Teknik penentuan sampel dengan pertimbangan tertentu. ${ }^{22}$

Secara lebih detail, penelitian ini menggunakan teori Teori Nomogram Harry King. Dalam Nomogram Harry King, jumlah populasi maksimal 2000, dengan taraf kesalahan yang bervariasi, mulai 0,03\% sampai 15\% dan faktor pengali yang disesuaikan dengan taraf kesalahan yang ditentukan. Dalam nomogram terlihat untuk Confident Interval (interval kepercayaan) 80\% faktor pengalinya $=0.780$, untuk $85 \%$ faktor pengalinya $=0,785$, untuk $95 \%$ faktor pengalinya $=1,195$ dan untuk $99 \%$ faktor pengalinya $=1.573$. Maka dengan populasi berjumlah 740 orang, dan dikehendaki sampel terhadap populasi $90 \%$ atau tingkat kesalahan 10\%, maka sampel yang diambil 0,11 x $740 \times 1,132=92.15$ atau dapat digenapkan menjadi 93 orang.

Maka dengan populasi berjumlah 740 orang, dan dikehendaki sampel terhadap populasi $90 \%$ atau tingkat kesalahan 10\%, maka sampel yang diambil 0,11 x $740 \times 1,132=92.15$ atau dapat digenapkan menjadi 93 orang.

\footnotetext{
${ }^{19}$ Uma Sekaran, Research Methods For Business Metode Penelitian Untuk Bisnis (Bandung: PT. Salemba Empat, 2006).

${ }^{20}$ Rioza Manda Rizal, Sanapiah Sanapiah, and Ade Kurniawan, "Persepsi Guru SDN 4 Teros Terhadap Pembelajaran Daring Di Masa Pandemi COVID-19," JPIn: Jurnal Pendidik Indonesia 3, no. 2 (2020): 36-41.

${ }^{21}$ Anita Choyrina, Adibah Jauhari, and Abdul Rouf, "Peran Pondok Pesantren Gadingmangu Terhadap Kesejahteraan Dan Akhlak Masyarakat Desa Gadingmangu Kecamatan Perak Kabupaten Jombang," Arsy: Jurnal Studi Islam 2, no. 1 (2018): 11-20. 2017).

${ }^{22}$ Sugiono, Metode Penelitin Kuantitatif, Kualitatif Dan R\&D (Bandung: Alfabeta CV,
} 


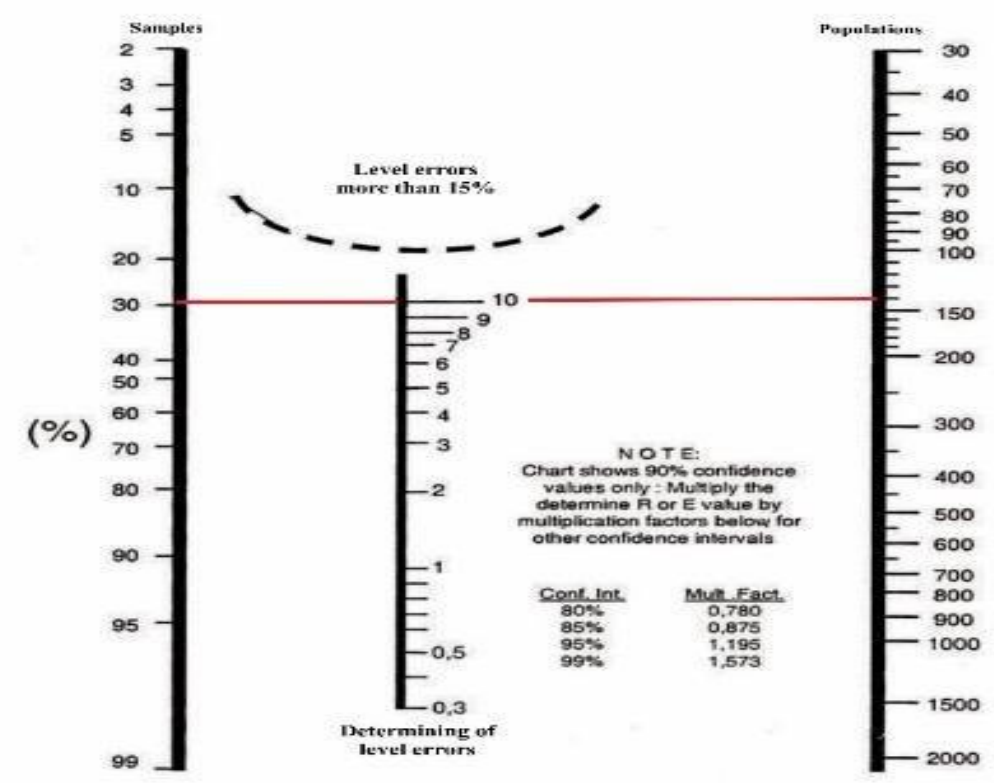

Ket. Tarik dari angka 740 (garis population) melewati taraf kesalahan 10\%, maka ditemukan titik di atas angka 10, titik itu kurang lebih berada di 11, untuk kesalahan $10 \%$ berarti taraf kepercayaan $90 \%$, sehingga faktor pengalinya $=1,132$.

\section{Hasil Dan Pembahasan}

Penelitian tentang keterlibatan mahasiswa dalam lembaga kemahasiswaan dan efektifitasnya dalam dakwah adalah suatu penelitian yang dilakukan untuk mengungkap data singkronisasi antara keterlibatan dalam Lembaga Kemahasiswaan dan maksimalisasi peran alumni STIBA dalam aktivitas dakwah secara khusus riset ini dimaksudkan untuk mengetahui: pertama, Sejauh mana keterlibatan mahasiswa STIBA dalam Lembaga Kemahasiswaan selama berstatus mahasiswa; kedua, Bagaimana efektifitas dakwah alumni STIBA di lokasi penugasan; ketiga, Analisis keterlibatan mahasiswa dalam Lembaga Kemahasiswaan terhadap efektifitas dakwah.

Penelitian ini melibatkan alumni STIBA Makassar periode tahun 2013-2018 dengan rincian alumni tahun 2013 sebanyak 13 orang, angkatan tahun 2014 tidak ada alumni, angkatan tahun 2015 sebanyak 11 orang, angkatan tahun 2016 sebanyak 9 orang, angkatan tahun 2017 sebanyak 9 orang, dan angkatan tahun 2018 sebanyak 53 orang, total sampling sebanyak 95 orang, mahasisawa 71 dan mahasiswi 24 orang. 
178 | Jurnal Dakwah dan Komunikasi, Vol.6 No.2, 2021

Tabel 1. Jumlah Sampel dan Populasi

\begin{tabular}{|c|c|c|}
\hline \multirow{6}{*}{ Th. Lulus } & 2013 & 13 \\
\hline & 2014 & 0 \\
\hline & 2015 & 11 \\
\hline & 2016 & 9 \\
\hline & 2017 & 9 \\
\hline & 2018 & 53 \\
\hline Jumlah (s) & & 95 \\
\hline Jumlah $(\mathrm{N})$ & & 740 \\
\hline Taraf Kesalahan & & $10 \%$ \\
\hline
\end{tabular}

Jumlah sampel $(\mathrm{s})=95$ orang dari total populasi $(\mathrm{n})=740$ orang, maka berdasarkan teori Nomogram Harry King maka tingkat kesalahan sampling mencapai $10 \%$ atau validasi data ini mencapai $90 \%$.

Tabel 2. Jumlah berdasarkan gender

\begin{tabular}{ll}
\hline Jumlah Alumni Ikhwan & 71 dari 386 \\
\hline Jumlah Alumni Akhwat & 24 dari 354 \\
\hline Jumlah sampel (s) dari populasi (n) & 95 dari 740 \\
\hline
\end{tabular}

Adapun hasil dari masing-masing penelitian dapat dirumuskan sebagai berikut:

\section{Keterlibatan mahasiswa dalam Lembaga Kemahasiswaan}

Selama menempuh pendidikan di STIBA Makassar, mahasiswa diharuskan untuk memilih salah-satu Lembaga Kemahasiswaan sebagai wadah untuk mengembangkan potensi diri. Dari hasil penelitian menunjukkan bahwa secara umum mahasiswa STIBA telah terlibat di dalam Lembaga Kemahasiswaan sebagaimana yang ditunjukkan dalam diagram berikut.

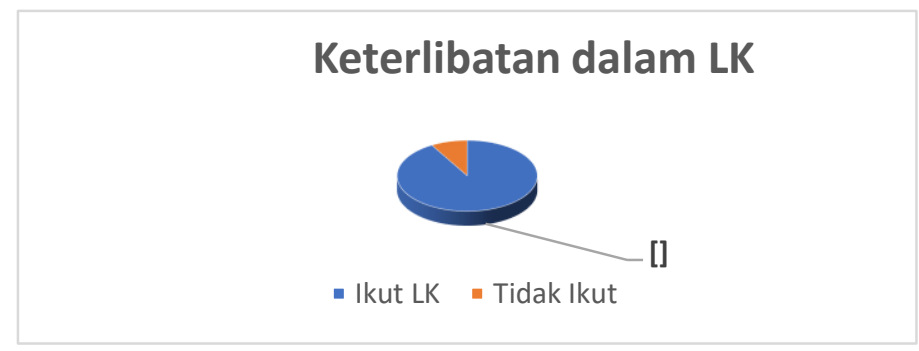

Gambar 1. Ketelibatan dalam LK

Data diagram di atas adalah data keterlibatan mahasiswa dalam Lembaga Kemahasisaan sebanyak 87\% terlibat dan 8\% mengatakan tidak terlibat. Dalam tataran Lembaga Kemahasiswaan, BEM, UKM Keasramaan dan BRTM masih lebih pasif dalam melakukan pencarian anggota dari Lembaga Kemahasiswaan yang lain. 
Di antara faktor yang membuat beberapa Lembaga Kemahasiswaan tersebut diminati mahasiswa karena lebih menarik dalam mengemas kegiatannya dibandingkan Lembaga Kemahasiswaan yang lain.

Dari pemaparan di atas, bidang kemahasiswaan STIBA kedepan diharapkan mampu menjadikan setiap Lembaga Kemahasiswaan mandiri dan kreatif dalam melakukan proses perekrutan anggota termasuk dalam hal mengemas kegiatan yang akan dilaksanakan.

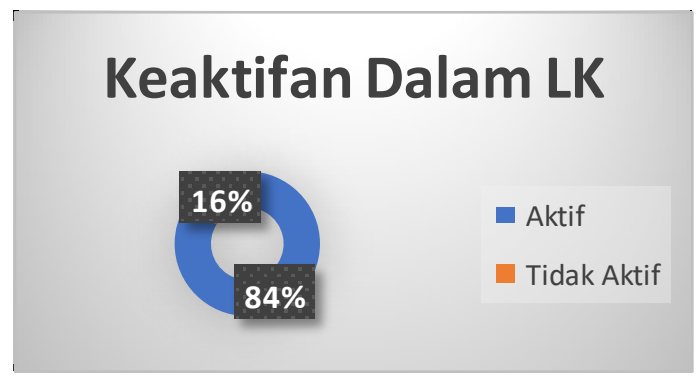

Gambar 2. Keaktifan dalam LK

Dari gambar 2, dari 87 orang yang bergabung dalam Lembaga Kemahasiswaan menunjukkan bahwa 73 orang atau $84 \%$ aktif sebagai pengurus, sedangkan yang tidak aktif sebanyak 14 orang atau 16\%. Mahasiswa aktif mengikuti Lembaga Kemahasiswaan tetapi sebagian mahasiswa tidak menemukan wadah untuk menyalurkan bakat. Dari data yang diperoleh, peneliti menilai bagaimana pihak kemahasiswaan mengupayakan solusi dari mahasiswa yang kurang dan tidak aktif dalam Lembaga Kemahasiswaan. Membaca kebutuhan mahasiswa dalam pengembangan diri sehingga mahasiswa terfalisitasi.

Olehnya STIBA Makassar disamping mempertahankan nilai positif yang dimiliki, juga mesti siap terbuka dengan kondisi di era disrupsi saat ini termasuk dalam pengembangan Lembaga Kemahasiswaan.

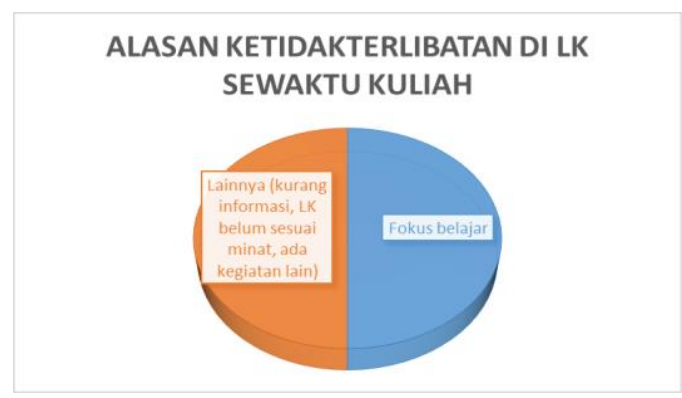

Gambar 3. Alasan Ketidakterlibatan di LK Sewaktu Kuliah

Dari gambar di atas, diketahui mahasiswa yang tidak terlibat LK 50\% ketidakterlibatan sebagai pengurus dengan alasan fokus belajar, dan 50\% dengan alasan beragam seperti kurang informasi, LK belum sesuai minat, ada kegiatan lain dan sebagainya. 
180 | Jurnal Dakwah dan Komunikasi, Vol.6 No.2, 2021

Solusinya, secara keorganisasian Lembaga Kemahasiswaan harus melengkapi perangkat organisasi di antaranya adalah petunjuk pelaksanaan organisasi yang memuat tupoksi dari setiap Lembaga Kemahasiswaan tersebut.

Dari data yang diperoleh mahasiswa kurang menjiwai dalam menjalankan amanah keorganisasian, sebagian yang lainnya mengambil amanah lebih dari dua lembaga kemahasiswaan. Tidak menjalankan musyawarah pekanan secara rutin serta pemilihan ketua yang tidak berjalan secara alami.

\section{Efektivitas dakwah alumni STIBA di Lokasi Penugasan}

Efektifitas dakwah adalah kemampuan mahasiswa STIBA yang meliputi:

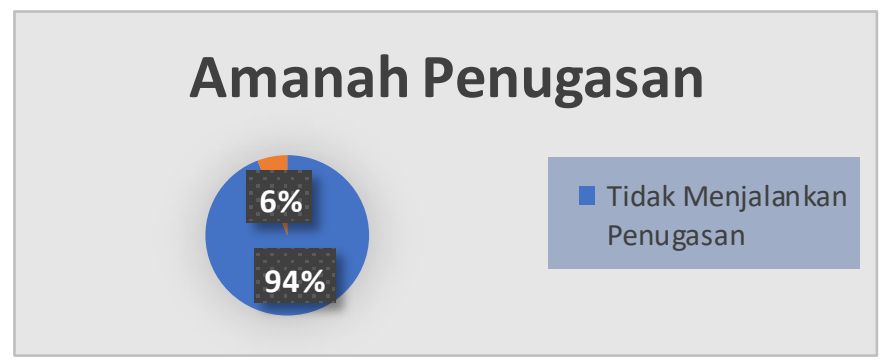

Gambar 4. Amanah Penugasa

Pada gambar 4, 94\% responden menyatakan sudah ditempatkan di lokasi penugasan masing-masing dan 6\% menyatakan tidak melaksanakan amanah penugasan sebagai alumni STIBA. Dari data tersebut, diharapkan bagian pemberdayaan alumni melakukan pendataan lulusan yang tidak melaksanakan pengabdian sebagaimana yang ditetapkan dan memberikan solusi untuk meminimalisir jumlah alumni yang tidak melaksanakan pengabdian.

Dari responden yang mengisi formulir, sebagian alumni STIBA Makassar telah aktif terlibat menjadi pengurus DPP WI, pengurus DPW WI, pengurus DPD WI dan pengajar di beberapa sekolah YPWI. Data ini menunjukkan korelasi positif antara keaktifan sebagai pengurus Lembaga Kemahasiswaan STIBA Makassar dengan amanah dakwah di lokasi tugas. Sehingga menggambarkan tingkat militansi alumni yang besar sesuai dengan keikutsertaan mereka di Lembaga Kemahasiswaan sewaktu berstatus sebagai mahasiswa.

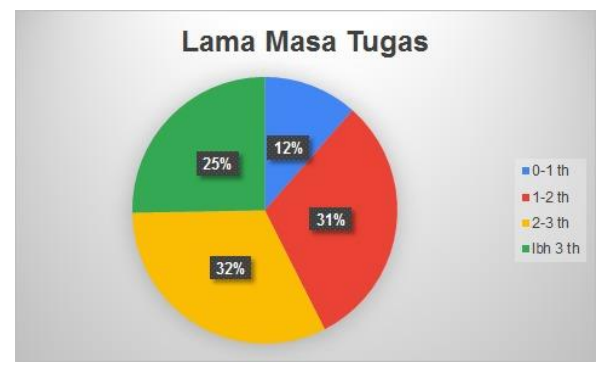

Gambar 5. Lama Masa Tugas 
Pada gambar 5, menunjukkan berapa lama alumni-alumni STIBA menjalani masa pengabdian yang diamanahkan. Sebanyak 25\% menyatakan telah mengabdi lebih dari 3 tahun, 32\% telah mengabdi sekitar 2 hingga 3 tahun, 31\% mengabdi kurang lebih 1 hingga 2 tahun dan 12\% menyatakan masih memulai masa pengabdian atau belum cukup satu tahun.

Data di atas menunjukkan bahwa keaktifan mereka sebagai pengurus Lembaga Kemahasiswaan dan keterlibatan dengan amanah dakwah belum berkolerasi positif dengan ketahanan mereka di lokasi tugas. Banyak hal yang mempengaruhi hal ini di antaranya:

1. Lokasi penempatan yang tidak sesuai dengan keinginan mereka

2. Faktor kesejahteraan berupa kafalah yang diterima

3. Pihak DPP WI/Lembaga diharapkan bisa lebih mengetahui kecendrungan dan potensi diri dari setiap alumni

4. Faktor istri/keluarga (orang tua)

5. Kemampuan mengelola dan mengembangkan potensi diri dari setiap alumni

6. Alumni belum maksimal memahami filosofi penugasan mereka di setiap DPD/MWD beserta tupoksinya

7. Alumni belum mampu mengejawantahkan materi-materi pembekalan yang sudah diberikan.

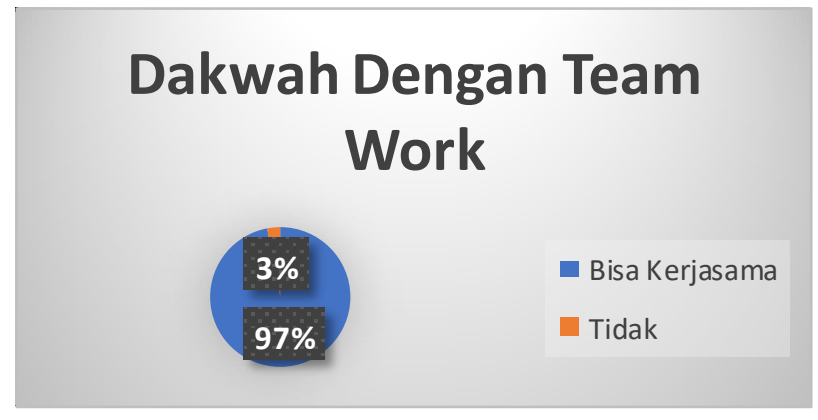

Gambar 6. Dakwah dengan Team Work

Gambar 6 adalah diagram yang menunjukkan kemampuan alumni STIBA $97 \%$ menyatakan mampu bekerja sama dengan tim dalam berdakwah. Data tersebut menunujukkan bahwa alumni siap senantiasa bekerja sama dengan pengurus yang lain, tidak ekslusif dan siap menempati amanah yang diberikan. Namun yang perlu dipertimbangkan bahwa mereka butuh pendampingan dan pengarah dari ketua DPD/MWD/Penanggung Jawab di lokasi penugasannya, karena realitasnnya sebagian DPD memberikan amanah yang besar di luar ekspektasi alumni tersebut dan menyamakan kemampuannya dengan alumni awal STIBA Makassar. 


\section{Kemampuan Memanfaatkan Media...}

$11 \%$

$89 \%$
Menggunakan

Media

Gambar 7. Kemampuan Memanfaatkan Media Berdakwah

Gambar 7 adalah diagram yang menunjukkan bahwa 89\% alumni yang telah ditugaskan menggunakan media elektronik dalam berdakwah. Data ini menunjukkan bahwa alumni yang ditugaskan mayoritas mampu menggunakan media sosial dalam berdakwah seperti facebook, instagram dan youtube walaupun kenyataanya menggunakan media elektronik seperti ini berangkat dari kemauan masing-masing dengan belajar otodidak sehingga diharapkan ke depan pihak kampus (Lembaga Kemahasiswaan) mampu memberikan pelayanan dalam pengembangan kreativitas mengelola media.

\section{Kemampuan Kerja Sama Dengan Tokoh... \\ $43 \%$ \\ - Mampu \\ - Belum Mampu}

Gambar 8. Kemampuan Kerjasama dengan Tokoh Masyarakat

Gambar 8 adalah diagram yang menunjukkan bahwa 57\% alumni STIBA telah menjalin kerja sama dengan tokoh masyarakat. Sementara 43\% lainnya belum mampu menjalin kerja sama dengan tokoh masyarakat.

Data di atas menunjukkan lebih dari sepertiga alumni yang di utus belum mampu melakukan interaksi dengan pihak eksternal. Banyak faktor yang mempengaruhi hal ini di antaranya:

1. Belum mendapatkan teknik bersosialisasi yang cukup

2. Materi pembekalan masih bersifat teoritis sehingga perlu diimbangi dengan praktik

3. Belum memahami urgensi kerja sama dengan tokoh masyarakat

4. Faktor pribadi/ karakter sebagian alumni yang masih bersifat esklusif

5. Perlunya kampus menanamkan kepercayaan diri alumni yang akan di tugaskan. 


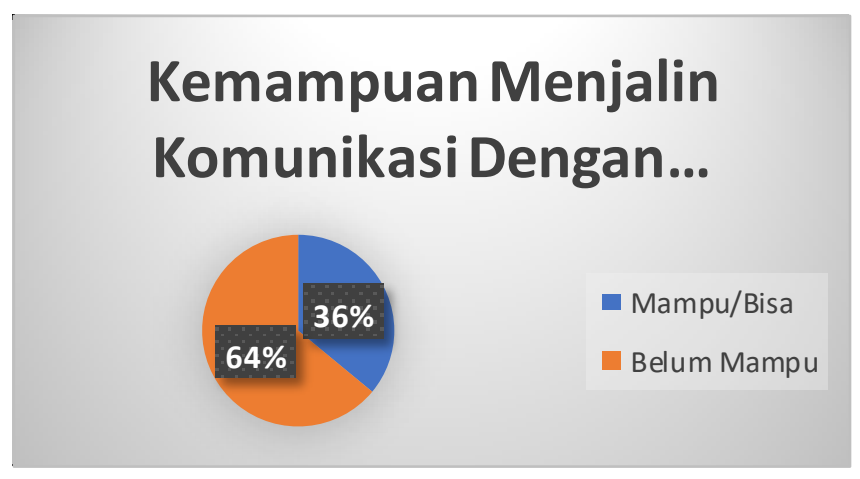

Gambar 9. Kemampuan Menjalin Komunikasi dengan Pemerintah

Adapun pada gambar yang ke-9 adalah diagram mengenai kemampuan menjalin kerja sama dengan unsur pemerintah. 64\% belum dapat menjalin kerja sama dengan unsur pemerintah sementara yang telah melakukan kerja sama dengan pemerintah sebanyak $36 \%$.

Data di atas menunjukkan lebih dari seperdua alumni belum mampu bekerjasama dengan unsur pemerintah ada beberapa faktor yang mempengaruhi di antaranya:

1. Belum memahami urgensitasnya

2. Belum mengetahui jalur berkomunikasi dengan pemerintah

3. Belum pernah mendapatkan pendampingan baik dari Lembaga Kemahasiswaan ataupun pengurus DPD/MWD setempat

4. Sebagian alumni belum percaya dalam menjalin kerja sama dengan pemerintah

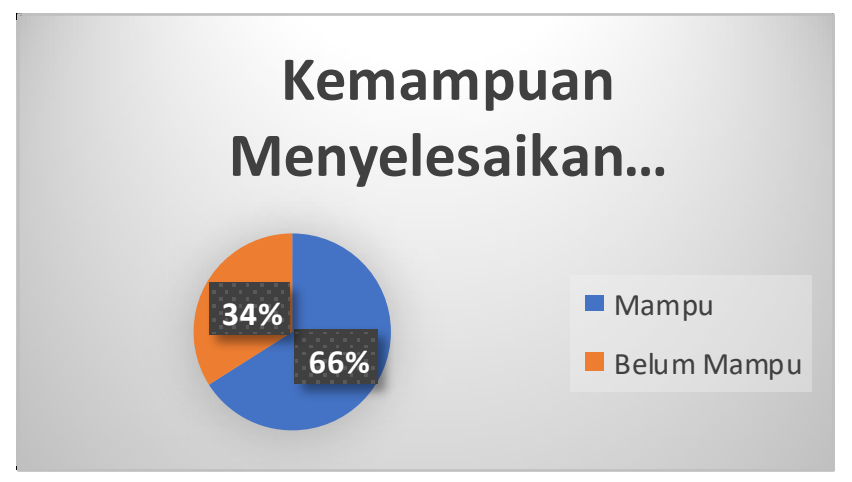

Gambar 10. Kemampuan Menyelesaikan Problamatika Dakwah

Data yang diperoleh, 66\% alumni mampu menyelesaikan problematika dakwah yang mereka hadapi di tempat penugasan mereka. Sementara itu 34\% dan lainnya menyatakan belum mampu menghadapi problematika yang mereka dapatkan di tempat penugasan. 
Dapat dilihat dari data tersebut, sebagian besar alumni yang ditugaskan bisa menyelesaikan tantangan dakwah yang dihadapi meski tidak dapat dipungkiri adanya beberapa alumni yang belum mampu. Hal tersebut tentu dipengaruhi oleh beberapa hal di antaranya:

1. Pengalaman dalam menghadapi problema saat menjadi Lembaga Kemahasiswaan yang masih kurang

2. Kurangnya pelibatan mahasiswa dalam kegiatan dakwah

3. Pemahaman tentang manajemen dakwah yang masih cendrung teoritis yang belum bisa diterapkan dilapangan.

Mengenai aktivitas atau bentuk kegiatan alumni di berbagai lokasi penugasan sebagaimana pada gambar, alumni STIBA banyak mengajar bahasa Arab, mengisi taklim, mengajar dirosa, mengisi khotbah Jumat, mengajar TK/TPA, menjadi wali santri dan berbagai kegiatan dakwah lainnya. Jika dicermati, kegiatankegiatan tersebut masih merupakan hal-hal yang berkaitan dengan internal organisasi dakwah yang mengutus mereka itu sendiri dan belum merambah ke kegiatan yang bersifat eksternal atau pada cakupan yang lebih luas.

Adapun posisi strategis yang ditempati oleh beberapa alumni, 8 Orang telah menjadi Ketua DPD, 4 orang ketua DPW dan 5 pengurus MUI. Ini di antara alumni yang mengisi formulir penelitian. Kemampuan dalam mengembangkan potensi seperti ini perlu diteliti oleh pihak STIBA sehingga diketahui pola pembinaan yang tepat bagi mahasiswa guna melahirkan lebih banyak alumni seperti di atas.

Berdasarkan beberapa pemaparan di atas, mahasiswa STIBA Makassar masih kurang dalam kemampuan melobi dan negosiasi dengan pemerintah, belum percaya diri menghadapi orang banyak, masih bersifat ekslusif serta belum memiliki kemampuan yang cukup untuk memobilisasi orang lain. Sehingga berdampak sebagian alumni yang ditugaskan masih cenderung menyelesaikan masalah yang bersifat internal organisasi.

\section{Analisis Keterlibatan Mahasiswa STIBA Makassar dalam Lembaga Kemahasiswaan terhadap Efktifitas Dakwah}

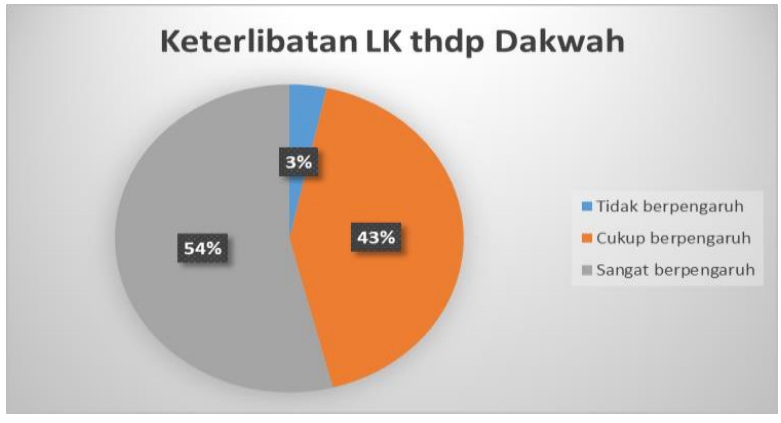

Gambar 14. Keterlibatan LK Terhadap Dakwah

Pada gambar 14,54\% menyatakan bahwa keterlibatan dalam Lembaga Kemahasiswaan sangat berpengaruh terhadap efektifitas dakwah di lokasi 
penugasan. Sedangkan 43\% menyatakan cukup berpengaruh dan 3\% lainnya menyatakan tidak berpengaruh. Berdasarkan data tersebut dapat diketahui bahwa dari beberapa faktor yang dapat meningkatkan efektifitas dakwah adalah keterlibatan dalam Lembaga Kemahasiswaan.

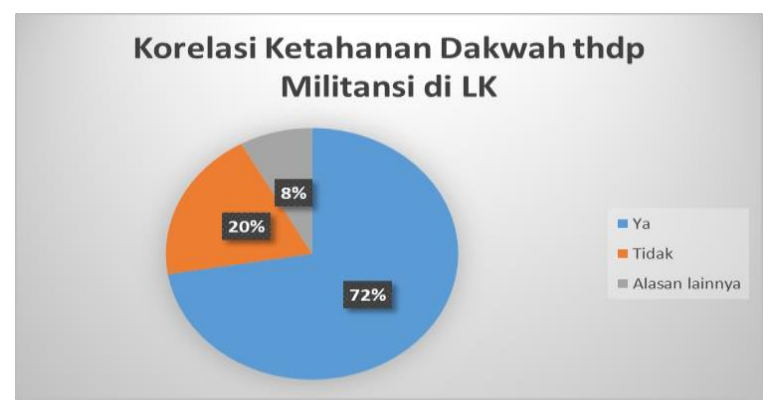

Gambar 15. Militansi Dakwah

Pada gambar 15,72\% menyatakan bahwa ketahanan dalam masa penugasan dipengaruhi oleh semangat militansi yang didapatkan selama bergabung di Lembaga Kemahasiswaan. 20\% menyatakan tidak sama sekali dan $8 \%$ menjawab yang lainnya. Peranan Lembaga Kemahasiswaan terlihat dari mayoritas responden yang menjawab bahwa ketahanan tersebut erat kaitannya dengan semangat militansi yang didapatkan selama bergabung dalam oragnisasi kemahasiswaan.

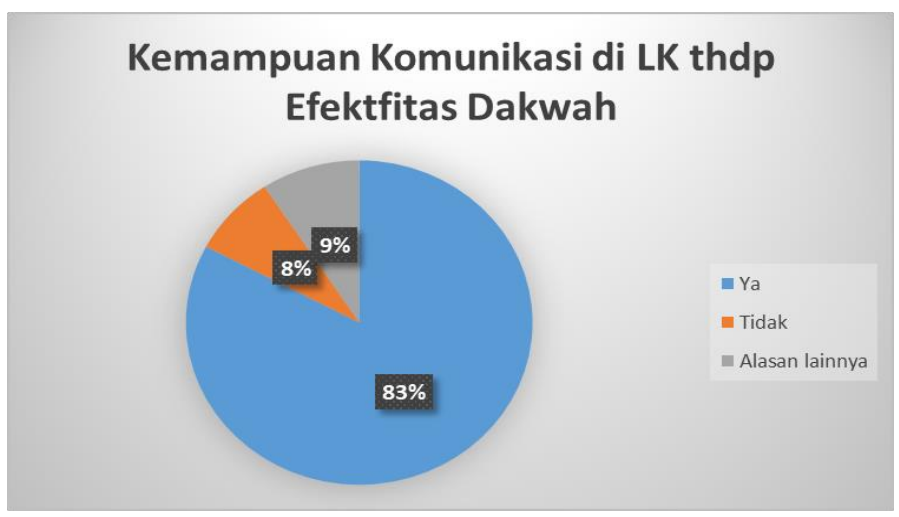

Gambar 16. Kemapuan Komunikasi di LK Terhadap Efektifitas Dakwah

Pada gambar 16, sebanyak 83\% menyatakan bahwa kemampuan berkomunikasi saat di Lembaga Kemahasiswaan berpengaruh dalam efektifitas dakwah di lokasi penugasan, 8\% menjawab tidak dan 9\% memilih alasan lainnya. Dari data tersebut, mahasiswa yang bergabung dalam Lembaga Kemahasiswaan dapat meningkatkan kemampuan mahasiswa dalam berkomunikasi yang kemudian sangat berpengaruh terhadap kiprah dakwah mereka di lokasi penugasan. 


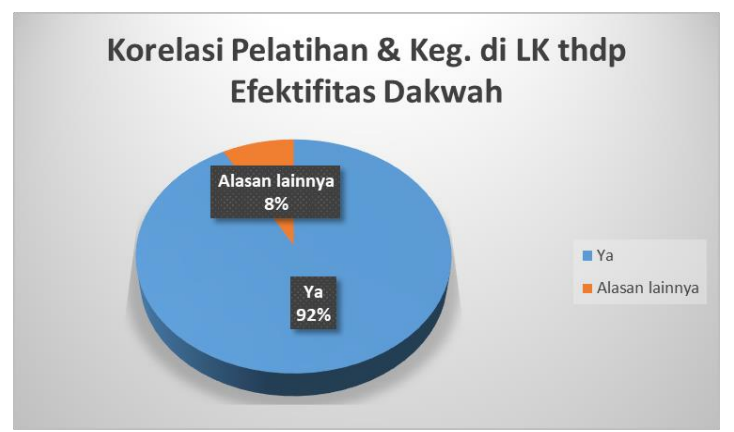

Gambar 17. Korelasi Pelatihandan Kegiatan di LK Terhadap Efektifitas Dakwah

Pada gambar 17, sebanyak 92\% menyatakan bahwa pelatihan dan kegiatan yang di dapatkan selama berada di STIBA Makassar sangat berpengaruh terhadap efektifitas dakwah, 8\% mengatakan dengan alasan yang beragam.

Dari beberapa pemaparan di atas, peneliti melihat bahwa Lembaga Kemahasiswaan berpengaruh tetapi belum maksimal karena pengaruh ini hanya bisa dirasakan untuk sebagian saja. Sementara gambaran alumni STIBA Makassar di luar adalah militansi yang kuat. Maka perlu dimaksimalkan kembali semua kegiatan kegiatan yang melatih ketemapilan mahasiswa seperti ketrampilan imam, khatib, kultum, keterampilan jahit, memasak dll.

\section{Penutup}

Dari pemaparan hasil penelitian di atas dapat disimpulkan beberapa hal sebagai berikut:

Pertama, Keterlibatan mahasiswa STIBA dalam Lembaga Kemahasiswaan selama berstatus mahasiswa cukup signifikan sebanyak 91,6\% sedangkan yang tidak terlibat dalam LK selama proses perkuliahan 8,4\%.

Kedua, Efektifitas dakwah alumni STIBA di lokasi penugasan diukur dengan tiga aspek, yaitu militansi, ketahanan, dan kreatifitas data menunjukkan bahwa militansiyang diukur dari masa tugas $<2$ tahun dari mahasiswa yang mengikuti LK sebesar 52,6\%, sedangkan yang tidak bertahan yaitu $>2$ tahun sebesar sebesar $38,9 \%$. Ketahanan yang diukur dengan kemampuan menyelesaikan problematika dakwah 57,5\% mampu menyelesaikan masalahnya, sementara 29,9\% belum mampu menyelesaikan masalah dakwah yang dihadapi. Indicator ketiga yaitu kreatifitas yang meliputi kemampuan menggunakan media dakwah, komunikasi tokoh masyarakat dan pemerintah, diperoleh data 55,5\% mampu dan 35,7\% belum mampu.

Ketiga, Keterlibatan mahasiswa dalam Lembaga Kemahasiswaan terhadap efektifitas dakwah berkolerasi positif sehingga upaya melibatkan mahasiswa di Lembaga Kemahasiswaan perlu untuk terus digalakkan disertai dengan upaya kreatif Lembaga Kemahasiswaan mengadakan kegiatan yang menarik bagi mahasiswa untuk menjadi pengurus. Ditemukan sebagian kecil mahasiswa yang tidak bergabung 
di Lembaga Kemahasiswaan juga mampu melaksanakan pengabdian $>2$ tahun sebanyak 5,3\%, sementara $<2$ sebanyak 3,2\%.

Saran dalam penelitian ini menunjukkan bahwa keterlibatkan dalam Lembaga Kemahasiswaan cukup signifikan namun mengalami penurunan dari tahun ke tahun. Faktor positif dari keterlibatan mahasiwa seperti antusiasme bergabung di BEM/DEMA dan Keasramaan. sosialisasi lembaga, serta perekrutan pengurus selayaknya dipertahankan dan ditingkatkan frekuensinya. Sementara hal yang menjadi faktor negatif baik yang sifatnya internal seperti tupoksi kerja yang kurang jelas dan kelengkapan perangkat organisasi maupun eksternal seperti kurangnya koordinasi untuk diminimalisir

Penelitian yang dilakukan merupakan suatu eksperimen dimana hasil yang diperoleh diharapkan dapat dijadikan suatu parameter dalam pertimbangan ataupun pengambilan keputusan dimana alumni STIBA Makassar mengusulkan beberapa kegiatan penunjang bagi seluruh mahasiswa yang sedang menjalankan studi di STIBA diantaranya kegiatan penunjang skill dan singkronisasi antara kampus sendiri dengan seluruh orang tua atau wali mahasiswa.

\section{Daftar Pustaka}

Almarogi, Ahmad. "Keterlibatan Senat Mahasiswa Universitas Dalam Tata Kelola Organisasi Intra Kampus: Studi Kasus Kampus Universitas Islam Negeri Sunan Gunung Djati Bandung.” UIN Sunan Gunung Djati Bandung, 2019.

Bungin, Burhan. Metodologi Penelitian Kuantitatif Komunikasi, Ekonomi, Dan Kebijakan Publik Ilmu-Ilmu Sosial Lainya. Jakarta: Kencana, 2005.

Choyrina, Anita, Adibah Jauhari, and Abdul Rouf. "Peran Pondok Pesantren Gadingmangu Terhadap Kesejahteraan Dan Akhlak Masyarakat Desa Gadingmangu Kecamatan Perak Kabupaten Jombang." Arsy: Jurnal Studi Islam 2, no. 1 (2018): 11-20.

Hendra, Faisal. "Peran Organisasi Mahasiswa Dalam Meningkatkan Mutu Pembelajaran Keterampilan Berbahasa Arab." Arabiyat: Jurnal Pendidikan Bahasa Arab Dan Kebahasaaraban 5, no. 1 (2018): 103-20. https://doi.org/10.15408/a.v5i1.7480.

Indriyani, Azizah. "Manajemen Sdm Dalam Upaya Meningkatkan Mutu Dan Kualitas Pelayanan Di Ridwan Institute Cirebon.” Syntax 2, no. 8 (2020).

Kosasih, Kosasih. "Peranan Organisasi Kemahasiswaan Dalam Pengembangan Civic Skills Mahasiswa.” Jurnal Pendidikan Ilmu Sosial 25, no. 2 (2017): 188-98.

Rupa, Martina Kaisriani. “Alasan-Alasan Mahasiswa/I Tidak Ingin Terlibat Dalam Organisasi Kemahasiswaan Di Perguruan Tinggi,” 2018. Yogyakarta.

Muhamad. Metode Penelitian Ekonomi Islam Pendekatan Kuantitatif. Jakarta: PT.Raja Grafindo Persada, 2008. 
188 Jurnal Dakwah dan Komunikasi, Vol.6 No.2, 2021

Nurdi, Putri Bayina Rahma, Syutri Laikuallo, and Alifia Meiliska. "Faktor-Faktor Yang Mempengaruhi Minat Mahasiswa Berorganisasi." Manor: Jurnal Manajemen Dan Organisasi Review 2, no. 2 (2020): 122-31.

Penelitian, Pusat, Pengabdian Masyarakat, Sekolah Tinggi, Ilmu Islam, and Bahasa Arab. "Panduan Penelitian STIBA Sumber Dana PNBP Dan Mandiri," n.d.

Permata, Ayu, Nova Yulita, and Sellia Juwita. "Pengaruh Pemahaman Ibu Tentang Perkembangan Motorik Anak Terhadap Perkembangan Motorik Anak." Jurnal Ilmiah Fisioterapi 2, no. 2 (2019): 44-49.

Putri, Menella Angelia, and Achmad Supriyanto. "Pembangunan Karakter Mahasiswa Melalui Keikutsertaan Dalam Organisasi Kemahasiswaan." In Seminar Nasional Arah Manajemen Sekolah Pada Masa Dan Pasca Pandemi Covid19, 2020.

Republik Indonesia. “UU No. 12 Nomor 2012,” 2012.

Rizal, Rioza Manda, Sanapiah Sanapiah, and Ade Kurniawan. "Persepsi Guru SDN 4 Teros Terhadap Pembelajaran Daring Di Masa Pandemi COVID-19.” JPIn: Jurnal Pendidik Indonesia 3, no. 2 (2020): 36-41.

Samsuddin, Samsuddin, Iskandar Iskandar, and Mariyanto Nurshamsul. "Pendidikan Kader Da'i Ormas Wahdah Islamiyah Melalui Halaqah Tarbiyah." Ta'dibuna: Jurnal Pendidikan Islam 9, no. 2 (2020): 283-300.

Sugiono. Metode Penelitin Kuantitatif, Kualitatif Dan R\&D. Bandung: Alfabeta CV, 2017.

Sujarwo, Sujarwo. "Peran Lembaga Kemahasiswaan Fakultas Dakwah Dan Komunikasi UINSU Dalam Menciptakan Keharmonisan Di Fakultas Dakwah Dan Komunikasi Universitas Islam Negeri Sumatera Utara." Universitas islam Negeri Sumatera Utara, 2017.

Suwarno, and Latifah Arifatul Farida. "Aktualisasi Bimbingan Dan Konseling Pada Pendidikan Dasar Menuju Peserta Didik Yang Berkarakter.” Prosiding Seminar Nasional Dan Call For Papers ISBN: 978-, no. 2 (2015): 323-32.

Uma Sekaran. Research Methods For Business Metode Penelitian Untuk Bisnis. Bandung: PT. Salemba Empat, 2006.

Yayasan Pesantren Wahdah Islamiyah. Statuta Sekolah Tinggi Ilmu Islam dan Bahasa Arab (STIBA) Makassar, Pub. L. No. QR.24a/YPWI/IX/1440 (2019).

Yunindra Widyatmoko. "pengaruh Keaktifan Mahasiswa dalam Organisasi dan Prestasi Belajar Terhadap Kesiapan Kerja Mahasiswa Jurusan Pendidikan Ekonomi Universitas Negeri Yogyakarta.” Universitas Negeri Yogyakarta, 2014. 